\title{
Temporariness, Rights, And Citizenship: The Latest Chapter in Canada's ExClusionary Migration AND RefugeE HISTORY
}

\author{
AMrita HARI
}

\begin{abstract}
Changes to Canada's immigration and refugee determination policies made since 2012 have increased the occurrence and persistence of temporariness in Canada, contributing to the systematic exclusion of a growing number of noncitizens, who live and work on the territory, from a wide range of rights. From the perspective of temporariness, I illustrate the striking similarities in the state's approach to two seemingly distinct groups of non-citizens (based on their rationale for admission): low-skilled temporary foreign workers and refugee claimants. Both groups occupy a low rung in the hierarchy of rights and entitlements to citizenship in Canada, inevitably affecting their social and economic outcomes in the host society. In conclusion, I argue that there is still much to be gained by viewing these distinct groups of temporary migrants as theoretically and experientially linked, in order to design effective policy and deter Canada from repeating its dark and exclusionary migratory past.
\end{abstract}

\section{Résumé}

Les changements aux politiques canadiennes d'immigration et d'admission au statut de réfugié depuis 2012 ont augmenté le caractère temporaire des séjours au Canada, contribuant ainsi à l'exclusion systématique d'accès d'un nombre croissant d'étrangers vivant et travaillant sur le territoire canadien à une variété de droits. Du point de vue de la précarité, cet article montre les ressemblances importantes dans la façon que sont considérés deux groupes distincts d'étrangers du point de leur admission : les travailleurs étrangers non qualifiés, et les demandeurs d'asile. Ces deux groupes occupent des places inférieures dans la hiérarchie des droits et de l'accès à la citoyenneté canadienne, ce qui affecte invariablement leur place sociale et économique dans la société. En conclusion, on avance qu'il y a beaucoup d'avantages à considérer ensemble, sur les plans théoriques et pratiques, ces deux groupes de migrants temporaires, afin de concevoir des politiques plus efficaces et d'éviter que le Canada répète les erreurs de sa triste et discriminatoire histoire en matière de migration.

\section{Introduction}

Trmat mmigration has been recognized as a cornerstone of nation building in Canada since Confederation in 1867. The chapter of Canadian immigration history discussed in this article begins during the post-Confederation settler era but is focused on the changes to immigration and refugee determination policies made since 2012. Historically, rights and entitlements to membership in the Canadian state were premised on territorial presence and the granting of permanent status. Contemporary membership in Canada's sociopolitical community is the ascription of permanent resident status and/or citizenship by the state. Incorporation into the nation remains more subjective. Nation refers generally 
to a sentiment of solidarity based on cultural similarity, but more importantly mutual recognition. ${ }^{1}$ Canadian nationality incorporates both of these elements and assigns an individual a place in the community and a say in the effective control of the state.

Canada, as an entity, can exercise sovereignty or control over its territory to some extent, epitomized by its immigration and refugee determination policies that are designed to reflect Canada's interests. By attaching specific rules and codes to each entry category, Canada effectively creates a hierarchy of rights to stay, access to the labour market, and entitlements to state membership for all non-citizens. Much like designating citizenship, designating "illegality" assigns an individual a political and juridical identity, as well as a specific social relation to the state. States perceive unwanted and/or illegal migration as an affront to national sovereignty. The "illegalization" and "criminalization" of some migrations, therefore, is intricately connected to a perceived "loss of control" by the government. ${ }^{2}$

Canada has responded to the wake of perceived threats to national security, heightened in the post-9/11 era, concerns over the perceived diminishment of control over its borders, and a dilution of national identity, by expanding its "security perimeter" - an ever-growing and ever-present discursive security blanket with a vague functional definition. ${ }^{3}$ Despite the active expansion of this blanket, Canada continues to accept what it considers to be unwanted immigration of persons it does not actively solicit.

Gary Freeman explains this passive acceptance of unwanted immigration by disaggregating migration policy into four distinct policy arenas: (1) managing legal migration through migration planning and selecting migrants to meet specific nationally prescribed immigration objectives; (2) controlling illegal migration by implementing border controls, employer sanctions, and visa requirements; (3) administering temporary worker programs; and (4) refugee determination and processing of what the state considers to be genuine asylum claims. This disaggregation of migration policy suggests that sweeping assessments of state control over its borders, even within the contemporary securitization era, must be replaced with more limited and specific claims. 4

Historically, Canada has always passively accepted unwanted immigration, particularly for humanitarian reasons, following the ratification of internationally legislated refugee protocols. Over time, it has also had to recognize individual rights, specifically for family reunification of labour migrants, invoked in the Canadian Charter of Rights and Freedoms, and the pragmatic challenges of controlling "illegal" migration. 5 As a post-9/11 securitized state, Canada has made concerted efforts to ensure that immigration and refugee determination, in tandem with citizenship laws, are associated with the essence of the nation, effectively transforming migration and refugee laws into the "last bastion of sovereignty."6

This article examines how Canada maximizes its limited sovereignty in administering migration and refugee claims, evident in the changes to the temporary worker programs and the processing of in-land asylum claims made since 2012. The argument is presented in two parts. First, I argue that these changes have increased the occurrence and persistence of temporariness for specific groups of migrants in Canada, contributing to the systematic exclusion of these growing numbers of non-citizens, who live and work in the territory, from a wide range of rights (including permanent status and/or citizenship, work, access to provincial workplace standards, and social assistance). Second, in adopting the perspective of temporariness, I argue that the recent changes illustrate striking similarities in the state's approach to two specific categories of non-citizens: lowskilled temporary foreign workers and refugee claimants.

Scholarly discussion on temporary foreign workers and refugee claimants often places them in analytical and political silos, in part as a result of the distinct rationales for admitting these two groups of migrants. This article is not intended to be a robust comparison by any account, but instead selects specific aspects of admission procedures, access to social assistance (with a focus on Ontario), provisions for family reunification, and entitlements to permanent status and citizenship, as they apply to these two groups. These seemingly distinct groups occupy a low rung in the hierarchy of rights and entitlements to citizenship in Canada, inevitably affecting their social and economic outcomes in the host society.

\section{The Evolution of Temporariness in Canada}

Canadian immigration policy has many purported goals, including humanitarian, family reunification, and foreign policy; however, a primary historical and contemporary use of immigration policy is as a tool of economic policy to meet immediate shortages in the labour market. Temporary foreign worker programs have always played a key role in meeting this objective. The historical programs designed primarily to recruit foreign domestic help and farm labour first paved the pathways for temporariness in Canada.

The delegation of domestic work to foreign women is a longstanding practice in Canada. Young English and Scottish women served British-Canadian families from the 1890 s to the 1920s, followed by Eastern European refugee women during the Second World War, who served one year as indentured domestics. The growing shortages of domestic help in the 1950 s were met with special programs for 
German women to enter Canada to become permanent residents, later expanded to include Italian and Greek women. The Caribbean Domestic Scheme, characterized by the most restrictive and coercive practices, was the first program of its kind to recruit women of colour to work as domestic workers in Canada (as opposed to white women arriving through earlier programs), but these women were categorically denied the right to permanent residence. ${ }^{7}$ Foreign farm workers were recruited through short-term permits, with no entitlements to permanent status, which emerged out of separate bilateral agreements with the Mexican and Caribbean governments.

The Non-Immigrant Employment Authorization Program (NIEAP), established in January 1973, replaced these dispersed and diverse temporary worker programs. NIEAP was intended to allow the Canadian government and employers to use immigration policy to meet short-term market interests more flexibly and effectively. ${ }^{8}$ Temporary foreign workers (TFWs) were restricted to a specific job and employer. The NIEAP eventually evolved into a bifurcated program with two general streams: one targeted at high-skilled workers and the other at low-skilled workers. This bifurcation persists in the contemporary Temporary Foreign Worker Program (TFWP), which has "undergone seismic changes in its purpose, size and target populations."9 The number of temporary foreign workers present in Canada (on 1 December) rose by 148 per cent between 2002 and 2008. Since 2008, the number of temporary foreign workers admitted annually overtook the number of permanent residents, in a trend that has continued since. ${ }^{10}$

Temporariness in Canada implies limited rights based on temporality (often limiting period of stay) and conditionality (rights conditional upon behaviour such as requirements to satisfy a specific employer to remain in the country). ${ }^{11}$ The number of persons holding temporary status in Canada is diverse, demonstrating a multitude of forms of temporariness. Specific to economic and labour migrants, Rajkumar et al. (2012) ${ }^{12}$ have conceptualized the forms of temporariness on the basis of a temporary-permanent divide: a permeable paper border for the transnational elite that is less permeable for the majority of temporary migrants. Canada offers privileged forms of temporariness and inclusive membership to those categorized as high-skilled while reserving restrictive and restricting forms of temporariness for those categorized as "low-skilled."

Rajkumar et al. (2012) identify three primary categories: (1) temporarily temporary (e.g., high-skilled temporary foreign workers who are eligible for expedited permanent residency through the Canadian Experience Class), (2) permanently temporary (e.g., seasonal agricultural workers), and (3) temporarily permanent (e.g., foreign-born permanent residents who could be deported upon violation of immigration and security laws). For the purposes of the discussion in this article, within the temporarily temporary category I would include asylum seekers awaiting a decision on their claim, which could result in permanent residence, if they are granted refugee status, or deportation if rejected. In the next two sections, I shall discuss the two distinct groups of non-citizens that demonstrate some striking similarities.

\section{Low-Skilled Temporary Foreign Workers}

The hallmark of the contemporary Temporary Foreign Worker Program is a formalized distinction between high-skilled and low-skilled work, in accordance with the National Occupational Classification, which the Canadian government uses to describe all work performed in the labour market. High-skilled temporary foreign workers (HTFWs) fall within Skill Level 0 (management occupations), A (occupations that require university education), or B (occupations that usually require college or vocational education or apprenticeship training). Low-skilled temporary foreign workers (LTFWs) fall within Skill Level C (occupations that usually require secondary school and/or occupation-specific training) and D (occupations with no specific formal educational requirements and that provide on-the-job training). ${ }^{13}$

Demand for TFWs has only grown since the establishment of historical programs to recruit domestic and farm labour to meet shortages in the Canadian labour market. Canada's Economic Action Plan 2014 states that Canada continues to experience significant skills shortages in many sectors and regions, and the TFWP helps to fill genuine and acute labour needs in order to create more opportunities for Canadians, but not at the cost of displacing Canadian workers. ${ }^{14}$ In the midst of aggressive immigration and refugee policy reform in 2012, the hiring of more than 200 temporary workers from China in northeastern British Columbia $^{15}$ and outsourcing arrangements made by the Royal Bank of Canada (RBC) ${ }^{16}$ sparked outrage from both the labour unions and the public, and garnered significant media attention. The Canadian government was pressured to introduce relevant legislative, regulatory, and administrative changes, announced under Canada's Economic Plan 2013, which were intended to reform the TFWP to respond to specific criticisms raised against it.

Despite the introduction of these changes, the numbers of temporary foreign workers are rising in all provinces; the increase is most pronounced in Alberta, where the largest percentage of work permits is issued to workers entering low-skilled occupations. ${ }^{17}$ The growing demand for workers in low-skilled occupations across all provinces prompted the government to introduce the Pilot Project for Hiring 
Foreign Workers in Occupations that Require Lower Levels of Formal Training (also known as the Low-Skill Pilot Project) in 2002. The program was further modified in 2007, allowing employers to hire persons for occupations requiring at most a high school diploma or a maximum of two years of job-specific training. In the 2012 and 2013 fiscal years, the government used the high and persistent demand for low-skilled temporary foreign workers as their rationale to make the pilot project a permanent fixture of the Canadian immigration system, now called the Stream for Lower-Skilled Occupations.

The flagship domestic worker and farm labour schemes remained in place but with some semantic and cosmetic changes being introduced and implemented. From 1973 to 1991, all foreign domestic workers were denied citizenship. Despite the introduction of the Points System in 1967 , the low wages of foreign domestic workers prevented them from applying as independent-class immigrants. Concerns over the harsh reality of the working and living conditions of domestic workers led to the creation of the 1991 Task Force on Immigration Practices and Procedures. The Foreign Domestic Movement was implemented in that same year and reformulated in 1992 as the Live-In Caregiver Program (LCP), permitting foreign domestic workers to apply for permanent residence, after completing two years of live-in domestic service in a private household. The main controversial features of the program remained in place: the live-in requirement and dependence on a single employer, ${ }^{18}$ notorious for exposing workers to long and undefined work hours as a result of the inseparability of work and home and a higher potential for abuse and exploitation, since reliance on a single employer would mean LCPs would be unlikely to file complaints for fear of terminated work permits (forgoing a the opportunity to transition to permanent status in Canada) and/or deportation.

The Seasonal Agricultural Worker Program (SAWP) replaced NIEAP in 1974 as a government-to-government program of managed migration exclusively between Canada and Mexico. The day-to-day administration of the program is carried out by a non-profit private sector organization, Foreign Agricultural Resource Management Services, federally incorporated in 1988 . Work visas are valid for a specific job, employer, and time period. Workers live in employerprovided housing, and employers are required to cover certain costs, including transportation and health insurance. ${ }^{19}$ Workers arriving under SAWP and the Agricultural Stream within the Stream for Lower-Skilled Occupations are unaffected by the recent reforms to the TFWP, since the Canadian government asserts that there continues to be labour shortages in this particular industry and that unfilled jobs are "truly temporary."

\section{Refugee Claimants}

Although the manipulation of temporary foreign worker programs to meet short-term labour shortages is a way for the state to exercise sovereign control over immigration, the exigencies of state interdependence in a globalized world, and international law that requires states to respect an emergent "law of migrants," requires all liberal-democratic states to respect the rights of persons and not just citizens (what Christian Joppke calls a novelty of the postwar era). ${ }^{21}$ Canada is no exception. In fact, Canada has a history of grand gestures of humanitarianism, allowing it to be seen as a "refugee haven," despite horrific historical instances of racist exclusion. The volume of historical refugee flows to Canada included the influx of United Empire Loyalists fleeing the American Revolution, and French Protestants as well as fugitive slaves from the United States after the abolition of slavery in Canada in $1834 .{ }^{22}$ Canada's humanitarian image was marred, however, by its refusing asylum to Jewish refugees in the 1930s, epitomized by the infamous statement that "none is too many." 23

Prior to the Second World War, Canadian nationhood incorporated ideas of desirable non-citizens as white (primarily Anglo-Saxon) "British subjects," and restricted the work, residency, and family reunification rights of all other non-citizens who did not fit these criteria. In the immediate aftermath of the war, Canada accepted a significant number of "desirable" refugees from Western Europe, Hungary, and Czechoslovakia, and limited "undesirable" immigration from Asia and the Caribbean. The development of international legal instruments and basic structures of legal protection for refugees significantly altered the demographic composition of Canadian refugees that arrived following the postwar period. After the United Nations Convention Relating to the Status of Refugees in 1951 in Geneva, and the 1967 United Nations Protocol Relating to the Status of Refugees were put in place, Canada began accepting refugees from outside the traditional European states, including thousands of Asians expelled from East Africa and refugee claimants arriving on boats from Southeast Asia.

The rationale for Canada's racist exclusion incorporated myriad tropes of the foreign Other, as vector of disease, agent of subversion, corrupter or the moral order, and debaser of national identity, requiring the exteriorization of threat, epitomized in the curious case of the public and policy reactions to arrivals by ship throughout Canadian history. Such arrivals account for approximately 0.2 per cent of total refugee arrivals over the past twenty-five years. Eight vessels carrying approximately 1,500 people brought as many refugee claimants as might arrive in just three weeks in any one of those twenty-five years. ${ }^{24}$ Yet, despite 
the statistically insignificant number of refugee claimants, arrivals by ship garner disproportionate political attention.

The first recorded arrival of the modern period is the Japanese ship Komagata Maru, which arrived in May 1914 carrying 376 South Asians who were marooned just off the Vancouver harbour. Following a two-month legal battle, the undesirable British subjects aboard the ship were refused the right to disembark and forced to return to India, where the passengers were imprisoned upon arrival and some killed. ${ }^{25}$ Once set, this precedent was maintained when the ship SS St Louis arrived in 1939 carrying just over 900 Jewish refugees escaping the Holocaust. Upon its return to Europe, the asylum seekers faced arrest and death in concentration camps. ${ }^{26}$

The next set of ships that fuelled similar public outrage and legislative retaliation did not arrive until forty years later, after Canada had removed explicit racist references from its immigration policy, acceded to the 1951 Convention Relations to the Status of Refugees and the 1967 Protocol, and established its first refugee determination process of inland claims in the 1976 Immigration Act. In 1986, a ship carrying 152 Tamils landed off the east coast of Newfoundland followed by a separate arrival of 174 Sikhs off the coast of Nova Scotia. These unauthorized arrivals sparked public and policy concerns of illegality, fraud, deceit, and accusations of exploiting the generosity of Canadians. Prime Minister Brian Mulroney issued an emergency recall of Parliament to table Bill C-84, the Refugee Deterrents and Detention Bill, giving new powers to immigration officers to turn back ships in international waters if they were suspected of carrying claimants and made provisions for new fines to be imposed on carriers as well as new powers of search, seizure, and detention. ${ }^{27}$ In the year that Bill C-84 took to be passed and implemented, Canada also ratified the UN Convention against Torture and Other Cruel, Inhuman or Degrading Treatment or Punishment. In 1999, four ships from China carrying fewer than 600 passengers appeared off the coast of British Columbia evoking similar public and political indignation and put the deterrence effect of these earlier measures into question.

The racist responses to historical arrivals by ship in Canada strike a chord with contemporary political reactions. The two most recent incidents of designated irregular arrivals and asylum seekers to Canada are the Ocean Lady in October 2009 and the MV Sun Sea in August 2010. The majority of the 500 Tamil passengers who arrived off the coast of British Columbia were detained immediately on the grounds that they were at "risk of flight." 28 The controversy engendered by these recent arrivals contributed to further legislative changes, adding to Canada's already complex and lengthy refugee determination process.
Protecting Canada's Immigration System Act (Bill C-31), originally named the Immigration and Refugee Protection Act, had its first reading in the House of Commons on 6 April 2011. The bill died when an election was called later that year. The controversial Bill C-31 resurfaced as Protecting Canada's Immigration System Act, carrying over modifications from Bill C-4, Preventing Human Smugglers from Abusing Canada's Immigration System Act, and Bill C-11, Designated Countries of Origin. Bill C-11 would empower the minister to designate countries for which nationals would not have access to appeal decisions about their refugee claims. Passed in June 2012 and brought into effect in December 2012, the act is intended to deal with the "refugee crisis" but has been criticized across the board by human rights advocates and scholars for gross violations of human rights.

At present, Canada accepts refugees through two streams: the Refugee and Humanitarian Resettlement Program and the In-Canada Asylum Program. ${ }^{29}$ Refugees arriving through the first program and the Private Sponsorship of Refugee Program arrive as permanent residents. The In-Canada Asylum Program allows people to make a claim at a port of entry or at a Citizenship and Immigration Canada office. If a claim is deemed eligible, it is sent to the Immigration and Refugee Board for a decision on refugee status. ${ }^{30}$ This program is often the most controversial because Canada is unable to select persons who apply for asylum under this program, which it perceives as a threat to sovereignty, security, and national identity.

The Canadian state employs several measures to intercept potential refugee claimants before arriving at a Canadian port of entry in order to make a claim. These measures include detention and removal, diplomacy, prosecution and punitive measures, particularly against smugglers, transnational enforcement practices, and harmonization of border policies such as the Canada-U.S. Safe Third Country Agreement, part of the Canadian federal Perimeter Strategy implemented in $2003 .{ }^{31}$ It is the persons who arrive and make a refugee claim under the In-Canada Asylum Program (refugee claimants) who hold temporary status in Canada.

\section{Some Striking Similarities, Despite Distinctive Rationales for Admission}

It would be too ambitious, given time and space constraints, to describe this article as comparative. Rather, the intention is to make a unique contribution to the much-needed discussion and debate on temporariness, and invite scholars to establish a research agenda that views Canada's diverse temporary migrant groups as potentially theoretically and experientially linked. For my contribution, I draw on the 
Protecting Canada's Immigration Act and amendments to the Temporary Foreign Worker Program under Canada's Economic Action Plan 2014, to reveal the ways in which the treatment of low-skilled temporary foreign workers and refugee claimants are the same or differ, and ideally some reflections on why.

The system of admission for both groups, based on the recent legislative changes noted above, is lengthier, complicated, more onerous (albeit in different ways for temporary foreign worker and refugee claimants), and, in the case of the TFWP, more expensive. The implementation of Bill C-31 significantly altered the claims process for asylum seekers who fall under the Safe Third Country Agreement or for those who are perceived to present security or criminality risks. It is interesting to note that the criteria to determine inadmissibility based on criminality both inside and outside of Canada has been significantly expanded.

One of the most important and controversial features of the bill is the creation of two streams of claimants: Designated Countries of Origin (DCO) and Designated Foreign Nationals (DFNs). The minister of citizenship and immigration now has the authority to designate countries whose nationals have reduced judicial, legal, and other rights in the refugee process. Designation is based on the minister's opinion that the country may have independent judiciary or democratic rights or quantitative factors such as a rejection rate of claims of at least 75 per cent (including withdrawn and abandoned applications), or a withdrawn and abandoned rate of claims of at least 60 per cent. DFNs are groups of people that the minister of public safety desig nates as irregular arrivals or those who are suspected to have been smuggled for profit, and therefore their claims cannot be processed in a timely manner. ${ }^{32}$

As part of creating a fast and flexible streamlined refugee determination process, nationals of DCO countries face shorter timelines for refugee hearings (30 to 45 days as opposed to 60 days for other claimants). The burden of proof rests with the claimant and with an increasing standard of proof required, the shorter timelines make it extremely challenging for claimants to acquire all documents and information to establish a successful claim in a timely manner. If unsuccessful in their claim, they cannot appeal to the Refugee Appeal Division. They are permitted to seek judicial review at the Federal Court but do not have an automatic stay of removal and have to wait 36 months before they can apply for a Pre-Removal Risk Assessment, all of which increases the potential for fast deportation. The designation of groups of people as "irregular arrivals" (DFN) subjects all persons over 16 years of age to mandatory detention. There is a growing body of evidence to suggest that detention puts an asylum seeker in the position of disempowerment, uncertainty, isolation, and humiliation, increasing the likelihood of depression and suicide. ${ }^{33}$ Even if they are accepted as persons in need of protection, they still face reduced rights and different treatment during the refugee status determination, including regular reporting to immigration authorities as well as a ban from travelling outside Canada for any reason. 34

In the midst of the ongoing reform under Bill C-31, the Canadian government faced significant public, media, and trade union outrage, sparking significant changes to the TFWP. The administration of the TFWP is a jurisdictional conundrum, as the federal government has jurisdiction over the entry and stay of workers; however, the protection of workplace rights is a provincial responsibility, with the exception of Employment Insurance (a federal responsibility). A key requirement under the TFWP is the Labour Market Opinion (LMO) process, which must be approved by Employment and Social Development Canada (ESDC, formerly known as Human Resources and Skills Development Canada, HRSDC).

Canada's Economic Action Plan 2014 incorporated four changes to the LMO process, specifically in response to controversial hiring of temporary foreign workers in $\mathrm{BC}$ and by RBC: (1) it suspended the accelerated LMO process previously applicable for prolonged or extensive (large numbers of workers) recruitment; 35 (2) introduced a \$275 user fee to eliminate the use of taxpayer money to facilitate the process; (3) added questions to restrict the outsourcing of Canadian jobs and ensure that employers have a firm plan in place to transition to a Canadian workforce over time; and (4) increased the government's authority to suspend and revoke work permits and LMOs if they suspect that the program is being misused..$^{6}$

Although programs for low-skilled TFWs import people who temporarily fill permanent vacancies, the LMO process is more onerous for employers wanting to hire workers filling low-skilled positions in the Canadian labour market, as well as for the selected worker. Employers of prospective low-skilled workers are required to advertise on an ongoing basis and for a longer period of time and in more venues, targeting specific underemployed communities, and post specific wages. Employers must provide accommodation and accept responsibility for workers' transportation costs to and from Canada, as well as their health-care costs for the first three months of their contract. ${ }^{37}$ Other critical changes were the removal of the wage flexibility that allowed employers to pay TFWs up to 15 per cent less than the prevailing wage, and changes to the language requirements identifying English and French as the only languages 
that can be used for recruitment (a particular response to the outcry from $\mathrm{BC}$ with regard to the specific recruitment of Mandarin-speaking workers). $3^{8}$

Most refugee claimants across all provinces can apply to Citizenship and Immigration Canada (CIC) for a work permit once their claims have been referred to the Immigration and Refugee Board (IRB). Not all refugee claimants who apply for a work permit get one. Unsurprisingly, a different set of rules applies to DCO claimants. They cannot apply for work permits until their refugee claims are accepted or 180 days have passed since their claims were referred to the IRB. ${ }^{39}$ Refugee claimants who are unable to acquire a work permit must demonstrate that they cannot support themselves without work and that their only alternative is to go on social assistance. They must also have completed their medical examinations. For those refugee claimants who are already receiving social assistance, they should include proof of this when submitting their applications to CIC. Social assistance available to refugee claimants varies by province. ${ }^{40}$

The rights to social assistance extended to persons admitted for humanitarian reasons in Canada does not extend to persons arriving as labour migrants, despite the fact that it is now recognized under international law and codified in the Convention on the Protection of the Rights of All Migrant Workers and Members of Their Families, which Canada has yet to ratify. Low-skilled TFWs are not entitled to social assistance anywhere in Canada; however, they make payments to the federal Employment Insurance program. An ESDC-approved employment contract provides workers with some protection, but ESDC has no regulatory authority to monitor employer compliance..$^{41}$ Legal protections in the workplace are dictated by province-wide employment standards, but these do not transfer well into practice for temporary foreign workers.

TFWs are unlikely to file a complaint against employers, and most workers have little or no experience with Canada's legal and social systems, face language barriers, and are more likely to concede to self-censorship and to be influenced by misleading information provided by employers. If and when a TFW does choose to contest a contractual violation through legal proceedings, the time constraints on a work visa present a practical barrier to successful litigation. The threat of possible detention, deportation, or repatriation provides employers with an additional measure of control to exact over TFWs. Moreover, employers increasingly practise "country surfing": fuelling competition between sending countries and threatening to switch supply countries if they are dissatisfied. ${ }^{42}$ Workers who wish to apply for a work permit with a new employer in the same industry are not authorized to work unless they undergo the LMO process once again, and the federal and the provincial government make little effort to match workers with employers who already possess an approved LMO. 43

Despite the greater access to social assistance available for refugee claimants in comparison to low-skilled TFWs, the most recent reforms limit refugee claimants' access to necessary and appropriate health care. The Interim Federal Health Program (IFHP) was established in 1957, delivered by Health Canada. Since 1995, CIC took over responsibility for providing eligible persons with immunizations, other preventative medical care, essential prescription medications, vision tests, some elective surgery, as well as prenatal and obstetrical care if they are not yet covered by a provincial and territorial health insurance plan. ${ }^{4}$

Pan-Canadian health organizations and professionals have voiced serious concerns about the Order Respecting the Interim Federal Health Program 2012. This order announced the ending of "health care coverage" for most pharmacy benefits and all vision, dental, and other supplemental benefits. The order also established ambiguous criteria for what constitutes "basic coverage"; 45 that is, products and services "of an urgent or essential nature." For all others, including rejected refugee claimants as well as DCO and DFN claimants, coverage for physician and hospital services is limited to services and products "needed to diagnose, prevent or treat diseases that pose a risk to public health, or conditions of a public safety concern," therefore categorically excluding them from previous IFHP provisions.

Access to appropriate and necessary health care has always been and continues to be a point of concern for migrant workers in Canada. The focus has been on the potential risk associated with disease importation by migrant workers; however, critical scholars have made the argument that this undermines the potential for adverse effects on migrant workers' health. The majority of low-skilled TFWs live in employer-provided accommodation, which in the case of farm workers can be dilapidated and overcrowded quarters with poor sanitation, poor ventilation, inadequate means to refrigerate or heat food, and insufficient hygiene facilities. Migrant workers can also be found in occupations with elevated workplace health and safety risks, and farm workers in particular experience common health problems with chemical exposure, as well as single-event or long-term musculoskeletal injuries. In an attempt to protect their jobs and in fear of deportation, migrant workers may be more likely to work longer hours or dangerous shifts, accept unsafe work when injured or ill, and less likely to request safety equipment or report workplace accidents.

Migrant workers holding legal employment authorizations are not eligible for publicly funded health care until three months following their arrival, during which they are eligible 
to apply for private insurance. There are three potential barriers to migrants purchasing private insurance: (1) an economic barrier in that some may not possess the funds needed to buy insurance; (2) a geographical barrier, in that many migrants work in remote or rural areas where clinics may not recognize private insurance or have the necessary diagnostic equipment to cater to specific workplace injuries and health concerns; and (3) time barrier, in that many migrants work long hours and may not have the time to seek health care if their off-work hours do not coincide with clinic hours. ${ }^{46}$

All these risks are elevated for non-status migrant workers who do not hold legal employment authorizations. Common barriers for both groups are linguistic and cultural differences, which may make persons within these groups less willing to seek treatment. Furthermore, medical professionals may not be trained to recognize the social context of migrant worker 47 or refugee claimant health, resulting in a failure to acknowledge, address, and treat their health concerns adequately.

Scholars have long contested the exploitation of lowskilled TFWs, arguing that it has in fact become normal ized and concealed, and is being continually reproduced using the notion that permanent residents and citizens can expect certain rights and entitlements that are not available to non-citizens with temporary status. Numbers of temporary foreign workers who are granted permanent status has grown from 11.7 per cent in 2001 to 32.1 per cent in 2010 of all persons. ${ }^{48}$ It is integral to note, however, that this right is effectively denied to both groups: low-skilled temporary foreign workers as well as disadvantaged streams of refugee claimants (DCO and DFN). The majority of low-skilled workers, including workers in the SAWP, are ineligible for permanent residence in Canada.

A dire consequence of the lack of a pathway to permanent residence is consequent restrictions placed on family (re)unification. Joseph H. Carens notes that states intend to prevent permanent settlement by often requiring potential migrants to forgo their fundamental rights to family (re) unification, as a condition of entry. 49 In the past, Canada strategically restricted family reunification of Chinese and South Asian migrants in order to discourage the permanent settlement of these undesirable non-citizens. Contemporary examples include Designated Foreign Nationals who are barred from applying for permanent residence in Canada for five years, so family reunification is deferred. Moreover, the ban on travelling outside of Canada, if accepted as persons in need of protection, also prolongs family separation. Although the TFWP has no regulatory bar to family members accompanying workers to Canada, there is a double standard created by the differences in the accompanying spouse's access to the labour market based on the skill level of the TFW. The spouse of a high-skilled TFW is eligible for an open work permit, and the couple's children are entitled to study permits. In contrast, the spouse of a low-skilled worker must obtain an individual LMO, and the worker is required to cover the travel costs of his spouse and accompanying children, presenting an added economic barrier to family reunification and eventually settlement.

\section{Conclusion}

Albeit a brief discussion, this article reveals the latest chapter in Canada's exclusionary migration history by tracking the trajectories of two specific categories of non-citizens-lowskilled temporary foreign workers and refugee claimantswho, despite being admitted to Canada on the basis of different rationales, share some similarities and differences in their treatment by the host country. I show how the recent legislative changes including Protecting Canada's Immigration Act and the amendments to the Temporary Foreign Worker Program announced under Canada's Economic Action Plan 2014, have increased the occurrence and persistence of temporariness for a growing number of non-citizens who live and work on the territory, but are systematically excluded from a wide range of rights, including access to work and provincial workplace standards, social assistance, family (re) unification, permanent status, and entitlements to citizenship. Although I did not present a robust comparison, in this concluding section, I highlight key arguments and provide future policy and research directions.

The system of admission for both groups is lengthier, more complicated, more onerous for the migrants, more expensive in the case of the TFWP, and provides for increased chances of rejection and deportation. Since admitted under a different set of rules, refugee claimants have access to social assistance but reduced rights to work, while low-skilled temporary foreign workers face a more restrictive labour market opinion (work permit) process and are admitted with a right to work but without rights to social assistance anywhere in Canada. A set of barriers common to both groups are linguistic and cultural differences, which may make persons within these groups less willing to seek help or even treatment from medical professionals, who may also lack the training necessary to recognize the social context of the migrant worker and/or refugee claimant. The recent changes to the Interim Federal Health Program limits refugee claimants' access to necessary and appropriate health care, which has always been a point of concern for migrant workers. Both groups face policies that restrict family (re)unification and entitlements to permanent status and citizenship.

There are some advantages available to one group that the other does not have access to; therefore, it would be 
difficult to suggest any blanket policy solutions, since the specific needs of both groups do differ. It is also important to recognize that both groups differ significantly in the sheer numbers admitted to Canada at any specific time. Common to both groups, however, is a need for increased access to social assistance, especially for low-skilled temporary foreign workers. There is a greater need for better monitoring of employer compliance of ESDC-approved labour market contracts and adherence to provincial workplace standards. Both groups also require increased access to necessary and appropriate health care. There are drastic improvements required for low-skilled TFWs, and simultaneously an urgent need for serious reconsideration of changes to the IFHP affecting refugee claimants. Most importantly, perhaps, is the need for increased opportunities to gain permanent status in Canada, which for lower-skilled TFWs is truly an unjust paradox, since their high-skilled counterparts are automatically entitled to this privilege.

Finally, I would like to acknowledge that there has been a profusion of scholarship on temporariness as a theoretical framework, its consequences on the lived experience of migrants themselves, ${ }^{50}$ as well as changing public consciousness and understandings of nationality in Canada. ${ }^{51}$ This body of research has acknowledged the need to fully understand who enters temporary categories and what happens to them after they arrive in Canada. There is still, however, as I have stressed before, ${ }^{2}$ a tendency to consider temporariness in analytical and political silos, primarily on the basis of migrants' category of and rationale for admission. I shall push once more for a systematic comparative and longitudinal account of who is temporary and, moreover, who is able to transition from temporary to permanent status, as this can better inform policy design and stop the Canadian state from reverting to its dark exclusionary past.

\section{Notes}

1 Benedict Anderson, Imagined Communities: Reflections on the Origins and Spread of Nationalism (London: Verso, 1983).

2 Nicholas P. De Genova, "Migrant 'Illegality' and Deportability in Everyday Life," Annual Review of Anthropology 31 (2002): 419-47.

3 Audrey Macklin, "Borderline Security," The Security of Freedom: Essays on Canada's Anti-Terrorism Bill, ed. Ronald Daniels, Patrick Macklem, and Kent Roach, 383-404 (Toronto: University of Toronto Press, 2001).

4 Gary Freeman, "Can Liberal States Control Unwanted Migration?" Annals of the American Academy of Political and Social Science 534 (1994): 17-30.

5 Christian Joppke, "Why Liberal States Accept Unwanted Immigration," World Politics 50 (1998): 266-93.
6 Catherine Dauvergne, Making People Illegal (New York: Cambridge University Press, 2008).

7 Abigail B. Bakan and Daiva K. Stasiulis, "Foreign Domestic Worker Policy in Canada and the Social Boundaries of Modern Citizenship," Science and Society 58 (1994): 7-33

8 Ibid. 23.

9 Delphine Nakache and Paula J. Kinoshita, The Canadian Temporary Foreign Worker Program: Do Short-Term Economic Needs Prevail over Human Rights Concerns? (Montreal: Institute for Research on Public Policy, 2010), http:// irpp.org/research-studies/study-no5/2 4 .

10 Ibid., 1.

11 A. Hari, S. McGrath, and V. Preston, "Temporariness in Canada: Establishing a Research Agenda," CERIS Working Paper Series 99 (2013), http://www.ceris.metropolis.net/wp-content/uploads/2013/04/CWP_99_Hari_ McGrath_Preston.pdf.

12 Deepa Rajkumar, Laurel Berkowitz, Leah F. Vosko, Valerie Preston, and Robert Latham, "Atthe Temporary-Permanent Divide: How Canada Produces Temporariness and Makes Citizens through Its Security, Work, and Settlement Policies," Citizenship Studies 16 (2012): 483-510.

13 Human Resources and Skills Development Canada, "National Occupational Classification Tutorial" (Gatineau: Skills and Labour Market Information Division), http:// www30.hrsdc.gc.ca/NOC/English/NOC/2006/Tutorial. aspx\#6.

14 Government of Canada, "Canada's Economic Action Plan 2014: Temporary Foreign Worker Program," http:// www.actioplan.gc.ca/en/initiative/temporary-foreign -worker-program.

15 "B.C. Mine's Temporary Foreign Workers Case Dismissed," CBC News, 21 May 2013, http://www.cbc.ca/news/canada/ british-columbia/story/2013/05/21/bc-temporary-workershd-mining.html.

16 Sunny Freeman, "RBC Foreign Workers Controversy a Sign of an Increasingly Anxious Middle Class," Huffington Post, 12 April 2013, http://www.huffingtonpost.ca/2013/o4/12/ rbc-foreign-workers-middle-class_n_3065554.html.

17 Nakache and Kinoshita, Canadian Temporary Foreign Worker Program, 4.

18 Bakan and Stasiulis, "Foreign Domestic Worker Policy," 10.

19 Kerry Preibisch and Jenna Hennebry, "Temporary Migration, Chronic Effects: The Health of International Migrant Workers in Canada," Canadian Medical Association Journal 183 (2011): 1033-8.

20 Government of Canada, "Canada's Economic Action Plan 2014."

21 Joppke, "Why Liberal States Accept Unwanted Immigration," 268.

22 Mary Liston and Joseph Carens, "Immigration and Integration Canada," in Migration and Globalization: Comparing Immigration Policy in Developed Countries, ed. A. Kondo and A. Shoten, 207-27 (Rochester, NY: Social 
Science Research Network, 2008), http://papers.ssrn.com/ $\mathrm{sol}_{3} /$ papers.cfm?abstract_id $=1808981$.

23 Irving Abella and Harold Troper, None Is Too Many: Canada and the Jews of Europe, 1933-1948 (New York: Random House, 1983).

24 Alex Neve and Tiisetso Russell, "Hysteria and Discrimination: Canada's Harsh Response to Refugees and Migrants Who Arrive by Sea," University of New Brunswick Law Journal 62 (2011): 37-46.

25 David Goutor, Guarding the Gates: The Canadian Labour Movement and Immigration, 1872-1934 (Vancouver: University of British Columbia Press, 2007).

26 Alison Mountz, "Embodying the Nation-State: Canada's Response to Human Smuggling," Political Geography 23 (2003): 323-45.

27 Gillian Creese, "The Politics of Refugees in Canada," in Deconstructing a Nation: Immigration, Multiculturalism, and Racism in 9os Canada, ed. V. Satzewich, 123-45 (Halifax: Fernwood, 1992).

28 Ashley Bradimore and Harald Bauder, "Mystery Ships and Risky Boat People: Tamil Refugee Migration in the Newsprint Media," Canadian Journal of Communication 36 (2011): 637-61.

29 Citizenship and Immigration Canada, "The Refugee System in Canada," http://www.cic.gc.ca/english/refugees/canada .asp

30 Ibid.

31 Sharryn Aiken, "Manufacturing 'Terrorists': Refugee, National Security, and Canadian Law," Refuge 19 (2001): 54-73.

32 Canadian Council for Refugees, "Overview of Bill C-31 Refugee Determination Process," rev. 21 February 2013, http://ccrweb.ca/en/refugee-reform.

33 Janet Cleveland, Cécile Rosseau, and Rachel Kronick, "The Harmful Effects of Detention and Family Separation on Asylum Seekers' Mental Health in the Context of Bill C-31." Brief submitted to the House of Commons Standing Committee on Citizenship and Immigration concerning Bill C-31, 2012.

34 Canadian Council for Refugees, "Overview of Bill C-31 Refugee Determination Process."

35 The Expedited Labour Market Opinion (e-LMO) Pilot Project was introduced in September 2007 to accelerate the application process in 12 "occupations under pressure" in Alberta and British Columbia. Completed applications from employers who qualify to participate are processed within about five business days of Service Canada's receiving them. In 2008, 21 new occupations were added to the e-LMO Pilot Project, including low-skill positions in construction, hospitality, food and beverage services, and residential cleaning. Nakache and Kinoshita, Canadian Temporary Foreign Worker Program, 5.

36 Government of Canada, Canada's Economic Action Plan 2014.
37 Sarah Marsden, "Assessing the Regulation of Temporary Foreign Workers in Canada," Osgoode Hall Law Journal 49 (2011): 39-70.

38 Government of Canada, Canada's Economic Action Plan 2014.

39 Community Legal Education Ontario, "Social Assistance for Refugee Claimants," http://refugee.cleo.on.ca/en/ refugee-steps/social-assistance-refugee-claimants.

40 Community Legal Education Ontario, "Work Permits for Refugee Claimants," http://refugee.cleo.on.ca /en/work-permits-refugee-claimants.

41 Judy Fudge and Fiona MacPhail, "The Temporary Foreign Worker Program in Canada: Low-Skilled Workers as an Extreme Form of Flexible Labor," Comparative Labor Law and Policy Journal 31 (2009): 5-46.

42 Kerry Preibisch and Leigh Binford, "Interrogating Racialized Global Labour Supply: An Exploration of the Racial/ National Replacement of Foreign Agricultural Workers in Canada," Canadian Review of Sociology 44 (2007): 5-36.

43 Nakache and Kinoshita, Canadian Temporary Foreign Worker Program, 21.

44 Canadian Healthcare Association, Changes to the Interim Federal Health Program: Position Statement, 2012, http:// www.cha.ca/wp-content/uploads/2012/11/IFHP-reform -policy-statement-November-2012.pdf.

45 Ibid., 4.

46 Preibisch and Hennebry, "Temporary Migration, Chronic Effects," 1036.

47 Ibid.

48 Government of Canada, "Immigration Overview: Permanent and Temporary Residents," 2011, http://www.cic.gc.ca /english/resources/statistics/facts2010/temporary/32.asp.

49 Joseph Carens, "Live-In Domestics, Seasonal Workers and Others Hard to Locate on the Map of Democracy," Journal of Political Philosophy 16 (2008): 419-45.

50 Patti T. Lenard and Christine Straehle, Legislating Inequality: Temporary Labour Migration in Canada (Montreal: McGill-Queen's University Press, 2012).

51 Luin Goldring and Patricia Landolt, eds., Producing and Negotiating Non-Citizenship: Precarious Legal Status in Canada (Toronto: University of Toronto Press, 2013).

52 Hari, McGrath, and Preston, "Temporariness in Canada," 25.

Amrita Hari is an assistant professor in the Pauline Jewett Institute of Women's and Gender Studies (BA Hons and MA, University of Toronto, and DPhil, University of Oxford). She is interested in broader questions around global migrations, transnationalisms, diasporic formations, and citizenship. She may be contacted at amrita.hari@carleton.ca. 